Supporting Information for

\title{
Cathodic Electropaint Insulated Tips for Electrochemical Scanning Tunneling Microscopy
}

Scott N. Thorgaard, Philippe Bühlmann*

University of Minnesota, Dept. of Chemistry, 207 Pleasant St SE, Minneapolis, MN, 55455

buhlmann@chem.umn.edu
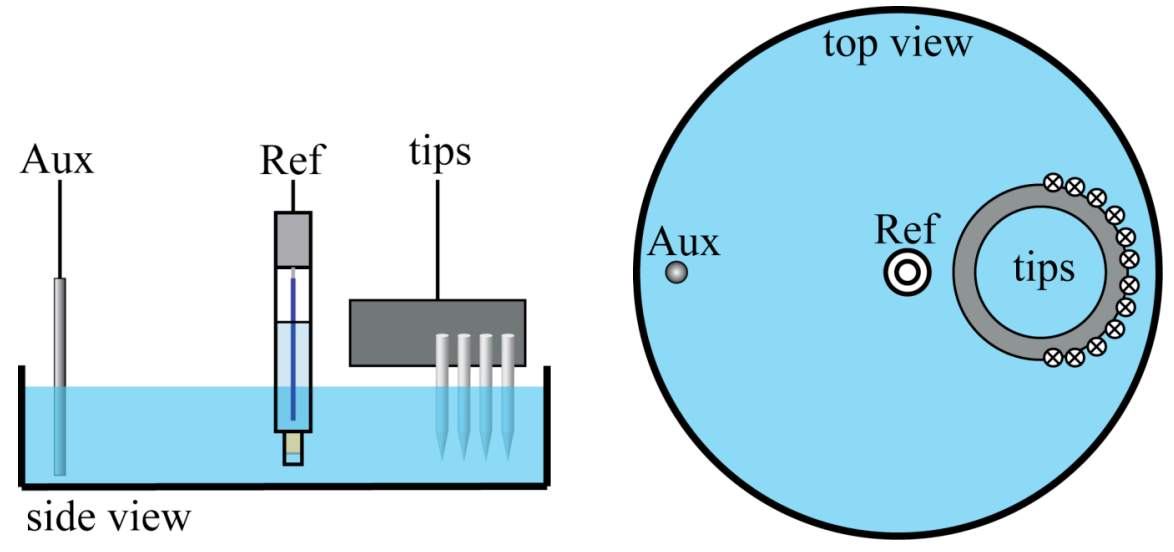

Figure S-1. Cell for paint electrodeposition. Tips are immersed approx. $7 \mathrm{~mm}$ in solution. Total volume of paint in the bath is approx. $30 \mathrm{~mL}$. 

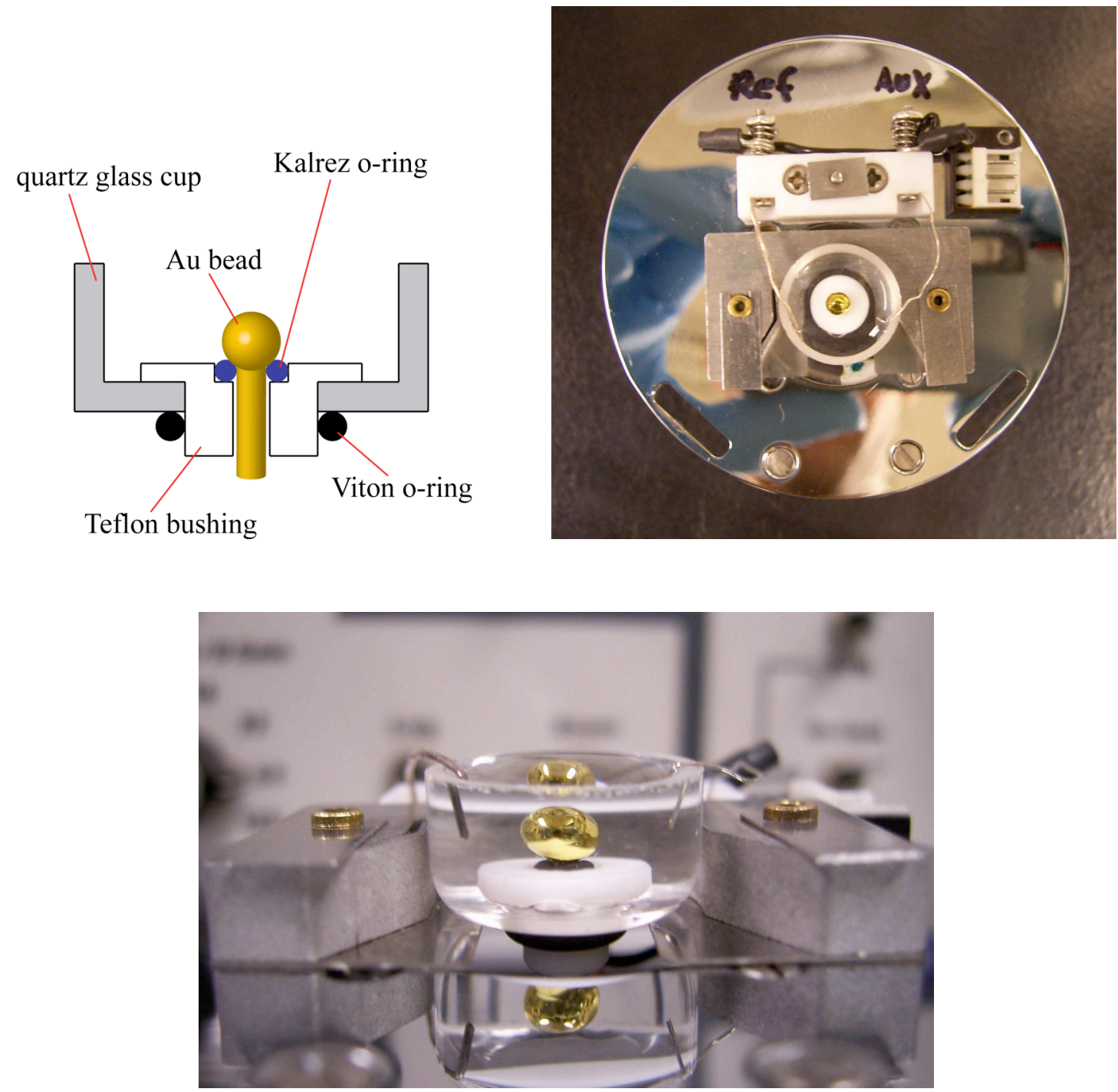

Figure S2. Diagram of the EC-STM cell and photos of the assembled sample stage with reference and auxiliary electrodes immersed. 